\title{
NEBRASKA HAS NO LOAN SHARK PROBLEM TODAY
}

\author{
Harold Johnson*
}

In the nineteen-thirties Nebraska was often referred to as the white spot of the nation because it was the only state of the union that had no bonded indebtedness. Nebraska was proud of that record which goes back some twenty years. It was but one of the many bright features of our local government. Among numerous others, this Cornhusker state also looks with pleasure and pride upon its successful accomplishments in dealing with the loan shark.

Its initial steps in exterminating the financial leeches were commenced almost forty years ago. In 1915 an act to regulate the lending of money was adopted which limited the rate of interest and charges. ${ }^{1}$ It was more than a mere enabling act, for it contained various regulatory provisions, some of which are common today in the most modern of small loan acts and the most recent of the model drafts.

We know today that the rgr5 act was not all that it should have been, fully and unflinchingly to stand the test of time and changing conditions. We know now that it was not sufficient to serve as an impenetrable dike forever to hold back the currents of guile, ingenuity, and resourcefulness of the unscrupulous and lawless. But it was a pretty good beginning. That was particularly so in view of the lack of a model to serve as a guide. We need only remember that this early Nebraska law was enacted prior to the first Russell Sage Model Draft and that even the Sage Model went through seven revisions before it was considered to be reasonably satisfactory and more or less set.

\section{EARLY ACT}

Under the act of 1915, any person who had the amount of the license fee and was able to furnish a $\$ 2,000$ bond, could obtain a license. There were no standards of character and fitness or of convenience and advantage. ${ }^{2}$ Supervision was under the Secretary of State and licensees were required to keep certain books and records and were subject to periodic inspections. ${ }^{3}$ The act required that receipts be given

* Assistant Director and Counsel, Department of Banking, State of Nebraska.

'Neb. Comp. Stat. $\$ \$ 45-112,45-126$ (1929).

2 The Act did provide that when application was made for a licence, "Protests misy be made by any person to the issuing of such license and when such protests are filcd with said secretary of state the latter shall give notice to persons whom he considers interested and hold a public heiring within two weeks on such protest before issuing such license. The said secretary of state shall have power to reject any application for licen.c alter hearing upon such protest" $(\$+5-114)$. In the absente of protest the secretary had no authority to deny a license. Virtually no protests were made betause there were no preseribed grounds for objection and there were no stundards to guide or control the secrctary in acting on a protest.

${ }^{3}$ Sec. 45-117. "The secretary of state is hereby charsed with the duty of inspecting the buxiness 
for payments and imposed limitations on the taking of assignments of wages and chattel mortgages, and imposed other requirements on the lender in making and collecting loans which were intended to protect the borrower. Under the I9I5 act, lenders were permitted to charge interest not to exceed the rate of Io per cent per annum and a brokerage fee of not more than one-tenth of the amount loaned. The act went on to provide: "No charge in addition to the said interest and brokerage fee shall be exacted, charged or collected, excepting an examination fee of not more than fifty cents on all loans not exceeding fifty dollars in amount." In the event of a renewal, extension or transfer, a new brokerage fee could not be charged for a period of six months. By way of further limitation and protection to the borrower, that act provided ( $\$ 45$-IIg):

The brokerage fee chargeable either upon original loan or upon a renewal, extension or transfer shall not be payable in advance but only upon final payment of loan. Interest shall not be payable in advance, and chargeable only upon unpaid balances. The examination fee hereinbefore provided shall be payable at the time of the making of the loan. A licensee shall not be entitled to any examination fee or any charge whatsoever unless a loan is actually made. If interest or charges in excess of those hereinbefore prescribed shall be received by any licensee, the said licensee shall thereupon lose all his right to collect or receive any sum whatever on said indebtedness.

Despite the apparent efforts to safeguard the public, the ingenuity of a few served to establish bridgeheads for unconscionable charges and objectionable practices.

\section{Abuses UNCOVERED}

In I94I, the operations of some shady lenders preying upon Nebraska citizens, especially in Omaha, came to the attention of the Governor and various members of the legislature. The Governor asked for legislation designed to stamp out those practices. As pointed out by William T. Foster in his article on "The Personal

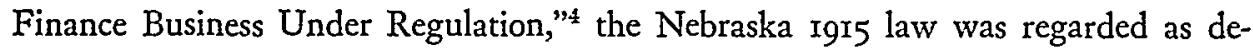
fective in that while it did bring in new capital, it did not keep out the very high-rate lenders. In that respect, we have already observed that the early law had no licensing standards and so the supervisory official had no practical control in rejecting the undesirable. Moreover, the general supervision was lax and indifferent and there were technical loop-holes in the law, particularly with respect to the manner in which the brokerage charge was stated. How right the Governor was in asking for improvements in the Nebraska small loan law was demonstrated by

rccords and accounts of all persons, firms, corporations or associations which lend money under the provisions of this act and is hereby empowercd to appoint deputy inspectors in each county in the state who shall, under the direction of the secretary of state, inspect the books and records of such persons, firms, corporations or associations annually and more often when directed to do so by the secretary of state and said inspectors shall be compensated for their services at the rate of five dollars per day for the time actually cmployed for such inspection and a full day shall consist of 8 working hours. Said compensation for said inspector' services shall be paid by the person, firm, corporation or association whose businese books and records are inspected" (Laws 1915, c. 204, \$6, p. 435).

-8 1.IW S CoNtemp. Prob. 154 (1941). 
the investigation conducted by the Banking Department when it took over the administration under the r94I act. An investigation and inspection of every lender in the state was required, with a view to licensing only those under the new law who were found to be fit. This resulted in a great "housecleaning." Nebraska contained a number of unscrupulous lenders who were taking advantage of the public by making exorbitant charges. Proceedings were commenced against these operators which resulted in some being placed in receivership, and all were stopped from operating in the state.

Investigations connected with cases against these companies required a tremendous amount of time and patience in interviewing the borrowers, obtaining the facts, and then calling upon them to testify. The trial of these cases extended into many weeks. If previously there had been doubts as to the need for an improvement in the small loan law in Nebraska, this investigation was without doubt the best thing that could have happened. First-hand knowledge was thus obtained of the conditions which actually existed prior to effective regulation.

In general the public was under the impression that these companies made but few loans, with no conception of the tremendous quantity of loans made by these "unscrupulous lenders" or the exorbitant charges involved. The investigation showed that charges of 300 per cent to 500 per cent per annum were being made by these "outlaws." Their customers were found to be people of most unfortunate financial circumstances. The pitiful examples of oppressed borrowers which came to the attention of investigators when interviewing these people in their own homes were indescribable. In many instances, people had borrowed only a small amount and were never able thereafter to get out of debt. Payment was being made continually month after month. In the process of cleaning up these conditions, the genuine need for a fully effective small loan law became understood, perhaps for the first time, converting the previous feeling of abhorrence toward small loan operations to one of enthusiasm for the future administrators of the act.

Time has added to the conviction of the department of the need for well regulated small loan service and demonstrated as well the economic place which well-operated small loan companies occupy in our modern life.

The Governor recommended that supervision of the small loan business be placed under the Banking Department. Parenthetically, it might be pertinent to observe that up until that time many of those in the Nebraska banking profession and, indeed, some of the executive personnel of the Banking Department itself, had a feeling of apprehension running almost into the realm of contempt for those in the small loan business and were imbued with the belief that such an activity was an evil to the economy and that persons so engaged were busily preying like parasites upon unfortunate victims and those of unequal bargaining power. It was, therefore, something of a bold step to propose that the supervision of that business be placed under the Banking Department which might be prone to give it unsympathetic 
guidance and treatment. Undoubtedly, experience in other states offered encouragement to the change in supervision which is now accepted so gratefully by those concerned.

\section{I94I ENACTMENT}

Now for some of the details of the comprehensive act passed in I94I. ${ }^{5}$ This act was a combination of certain features of the Russell Sage Drafts and the $1915 \mathrm{Ne}$ braska Act. It was a remedial act in a true and full sense. Administration was transferred to the Banking Department from the Secretary of State. Strict qualifications for a license were established, by imposing the new customary standards of character and fitness as well as of convenience and advantage. On the theory that a loan ceiling of $\$ 300$ or $\$ 500$ was not sufficient to satisfy the requirements in Nebraska and also in view of the reduced purchasing power of the dollar, the legislature took the forward looking view that the maximum amount of loan should be fixed at $\$ I, 000$. (Actually, the I94I act limited the service charge on loans of $\$ I, 000$ or less, and the loan ceiling of $\$ 1,000$ was established by the 1943 amendment.) Many other states have now also pushed the loan ceiling beyond the $\$ 300$ and $\$ 500$ limitations taking into consideration changes in conditions and requirements. ${ }^{6}$ Interest was limited to 9 per cent per annum and a service charge of one-tenth of the amount of the loan up to $\$ 1,000$ was authorized. The service charge was based upon a period of one year and was to vary proportionately for periods of more or less than a year.

The Department of Banking was authorized to issue rules and regulations (now administratively determined to be unnecessary); to regulate dual business; to issue cease and desist orders; and to prescribe the form of annual report. Advertising and wage buying were placed under control.

The I94I act was amended in I943 so that the Nebraska law now more nearly conforms to the Russell Sage Seventh Draft except as to insurance and the maximum amount of loan. Several of the larger companies operating in Nebraska were also doing business in other areas, including surrounding states, and for sake of uniformity, they urged a revision in the statement of the rate. These lenders were successful in their efforts and the maximum charges were expressed in an overall per cent per annum basis. The limitation became $3^{6}$ per cent per annum on the first $\$ 15^{\circ}$ of the amount of the loan and 30 per cent per annum on that part of the loan between $\$ 150$ and $\$ 300$, with a maximum of 9 per cent on the remainder of the loan up to $\$ \mathrm{r}, 000$.

ENeb. Rev. Stat. $\$ \$ 45-114,45-162$ (1943).

- Other states having a ceiling of $\$ r, 000$ or more are:

Ohio $\quad \$ 1,000 \quad$ Nevada $\quad \$ 1,500 \quad$ South Dakota $\$ 2,500$ Wyoming $\quad \$ x, 000 \quad$ Maine $\$ 2,500$ California $\$ 5,000$ Although the ceiling under the small loan law is $\$ 300$ in the states of Arizona, Colorado, Maryland, Massachusetts, New Hampshirc, Rhode Island, Utah, and Wisconsin, under separate laws small loan companies in those states may make loans up to the following amounts: Arizona, $\$ 1,000$; Wisconsin, \$2,000; Colorado, Maryland, Massachusetts, New Hampshire, Rhode Island, and Utah, no ceiling. 
The r94I act as amended will be discussed here in some detail. Subject to a few clarifying amendments in 1953 which will be reviewed later, the act as amended in r 943 is still in effect.

Thus far, there is no indication that the permissible rate of charge is any greater than it should be. As is true in most regulated states, the Nebraska rate is fixed by the legislature and is deemed adequate to return a reasonable profit to the lenders. If the rate is too low, legitimate lenders will leave the field to be replaced again by "loan sharks" as was demonstrated by the recent experience in Missouri" as well as that in New Jersey ${ }^{8}$ some years ago. The experience in Nebraska indicates that the present rate is a fair one. For instance, the 1952 Consolidated Annual Report issued by the Nebraska Department of Banking and covering the r4o licensed small loan companies, shows that the per cent of net earnings calculated upon average assets employed when computed before interest was paid on borrowed money was 7.28 per cent; when computed after interest was paid on borrowed money, it was 3.86 per cent.

Even though the act has a $\$ 1,000$ ceiling, generally lenders confine their loans to amounts not in excess of $\$ 500$ to $\$ 700$, depending upon the circumstances of the lender, the habits and practices in the particular locality, and other factors. In many cases, the risk of making a $\$ 1,000$ loan to an applicant, usually without any real or sufficient security, is acknowledged to be too great. At the same time, Nebraska is essentially a farm state and many of the customers of the small loan companies have seasonal income with need for-larger sums to tide them over for a period of time, and in addition, many are self-employed farmers and others who have requirements of larger sums for equipment and supplies. The need for the $\$ 1,000$ ceiling is very well justified and the fact that the average loan may be less than $\$ 500$ is not a material factor here in measuring the amount of the ceiling. The following classification of loans by size shows that more than 25 per cent of all loans made were within the bracket of $\$ 150$ to $\$ 300$; another 25 per cent in the bracket of $\$ 300$ to $\$ 500$; and the total number of loans in amounts in excess of $\$ 500$ represented less than 25 per cent of all loans made under the small loan law.

${ }^{7}$ On July I, 1946, Section 44 of Article III of the Missouri Constitution became effective, which prohibited classification of lenders for the purpose of legislation fixing maximum rates of interest. The Missouri Supreme Court held that the section repealed the small loan law, but the general interest rate of 8 per cent per annum remained in effect. Law abiding lenders were forced out of the state because no adequate rate was provided. Many loan sharks returned. As reported by Joe B. Birkhead (Missouri Cturbs Loan Sharks, Quarterly Report, published by Conference on Personal Finance Law, Summer, 1951, p. 70), the long fight to rid Missouri of the loan sharks who had come in in the interval since 1946 was concluded on May 8, 1951, when the Governor signed Senate Bills 78 and 79.

${ }^{8}$ In 1929 the New Jersey legislature reduced the rates on loans up to $\$ 300$ or less to a maximum of $1 \frac{1}{2}$ per cent per month. Most of the law abiding licensed lenders withdrew from the state because they could not operate at that rate. In 1932 the New Jersey legislature adopted a small loan law similar to the Russell Sage Fifth Draft. It authorized a maximum rate of charge of $2 \frac{1}{2}$ per ecnt per month on loans of $\$ 300$ or less. Legitimate lenders returned to the state thereafter to the extent permitted under the convenience and advantage licensing standard. 


\section{Classification of Loans by Size}

Small loans made during the year:

(a) Loans of $\$ 25.00$ or less

(b) Loans of $\$ 25.01$ to $\$ 50.00$

(c) Loans of $\$ 50.01$ to $\$ 150.00$

(d) Loans of $\$ 150.01$ to $\$ 300.00$

(e) Loans of $\$ 300.01$ to $\$ 500.00$

(f) Loans of $\$ 500.0$ r to $\$ 750.00$

(g) Loans of $\$ 75^{\circ} .01$ to $\$ 1000.00$

(h) Total small loans made

\section{Number of} Accounts

$$
\begin{array}{r}
r, 34 I \\
4,623 \\
20,958 \\
28,886 \\
25,466 \\
13,278 \\
10,304 \\
\hline 104,856
\end{array}
$$

Amount

$\$ 30,042$

I99,885

$2,133,072$

$6,501,407$

I0,39ז,604

$8,092,462$

$\frac{9,5^{89,726}}{\$ 36,93^{8,198}}$

\section{Licensing Standards}

As has already been indicated, one of the very important deficiences of the early Nebraska law was the absence of licensing standards, including character and fitness and convenience and advantage. It is most fortunate that they were included in the I94I act for they are more important than the bond requirement. (It is appropriate to note that in Colorado, Utah, and Virginia recent small loan enactments have omitted the bond requirement and New York state removed the bond requirement by legislative enactment in $1953 .^{\circ}$ Two other states, South Dakota and Wyoming, enacted small loan laws in 1953 , both of which omit mention of a bond.) There have been those who have been opposed to the convenience and advantage standard on the theory that it interferes with free enterprise. That standard should be applied only to the extent that it is necessary to prevent over-crowding in the lending field which in turn brings about an over-extension of credit and in turn redounds to the distress of the borrowers who have been over-loaded and who then become subject to extreme collection practices.

An effort was made at the 1947 session of the Nebraska legislature to remove the convenience and advantage clause from the Nebraska small loan law (L.B. 262). The bill was defeated in the unicameral legislature on April 4, I947 by a vote of $3^{\circ}$ to 7 , with 6 members not voting. The editorial page of the Nebraska Lincoln State Journal for April 5, I947 carried the following comment on the legislative action:

In killing the Benesch bill that would have permitted anyone to enter the small loan business the legislature was merely carrying out a policy with respect to public supervision of financial institutions that was found necessary some twenty-five years ago in the regulation of banking. Under the terms of the banking act no charter may be issued unless the department head finds it is necessary to the convenience and advantage of the public, and this provision is carried in the small loans law. Under the conditions that existed before the twenties no limitation was placed on the number of banks that could be started. The result was that more than a thousand were in operation, three or four times as many as more recent experience has shown were needed. To have eliminated the convenience and necessity clause in the small loan act would have brought back the private loan shark and made impossible the close supervision now in effect.

\footnotetext{
${ }^{\circ}$ See Wiesner, New York Bond Requirement Eliminated, Quarterly Report, published by Conference on Personal Finance Law, Summer, 1953, p. 7r.
} 
Later, under date of May 22, I95x, the Supreme Court of Nebraska held the convenience and advantage licensing standard to be constitutional in the case of Motors Acceptance Corporation v. McLain, Director of Banking.10 The court declared that the restriction of the number of licenses was necessary to accomplish the purpose of the act and that the convenience and advantage limitation was not violative of constitutional provisions as conferring arbitrary powers where an adequate appeal to the courts is provided. It cannot be said, the court ruled, that the administrative order denying a license, which is sustained by the evidence showing a reasonable relation to the regulation of the business, is unreasonable and arbitrary. ${ }^{12}$

\section{Rules and Regulations}

By Section 45-I29 of the Act of I94I, the Department of Banking was authorized and empowered to make general rules and regulations and specific rulings, demands, and findings as might be necessary for the proper conduct of the small loan business and the enforcement of the small loan law, not inconsistent with that law. Rules and regulations were promulgated as authorized by that Section. Under date of December 13, 1946, however, the Nebraska Department of Banking, Small Loan Division, issued an order repealing all rules and regulations which it had promulgated under the small loan law. The repeal was based on the following considerations:

I. There seems to be a tendency in both state and federal governments to have too extensive rules and regulations.

2. The law itself appears to be sufficiently broad to cover all of the subjects included in our rules and regulations.

3. The licensees have demonstrated their desire to operate within the limitations prescribed by the law and within the scope of the intent of the act. We have confidence in their continued cooperation after the repeal of such regulations.

The Iowa Department of Banking also repealed the rules and regulations which it had issued under the small loan act. Some five years after the repeal of those regulations in Iowa, Mr. Otis L. Jones, Supervisor, Small Loan Division, Iowa Department of Banking, publicly stated:

${ }^{10} 154$ Neb. 354, 47 N.W. 2d 9 19 (1951).

11 The evidence submitted on behalf of the Department in support of its refusal to grant the license was confined largely to the following points:

"x. Inadequate return or profit by the existing licensees in Omaha due to the excessive competition. The average return upon assets used in the small loan business during the year 1948 was approximately 4 per cent.

"2. An exhibit showing more licensees per capita than any other city of comparable size. A comparison was made of the number of licensees per capita per family per buying power per retail sales between the city of Omaha and cities of comparable size throughout the nation, revealing that Omaha was overlicensed in comparison with other communities.

"3. A tabulation showing all agencies in the city of Omaha engaged in the business of making consumer loans revealing that there were already 95 of such agencies engaged in this business, including credit unions, banks, small loan companies, and other institutions.

"4. A showing that the applicant was not in the small loan business and contemplated making loans only upon automobiles to a class having an above average credit risk; that this class of limited service would not be for the convenience and advantage of the community." Quarterly Report, published by the Conference on Personal Finance Law, Summer, 1951, p. 86. 
Our experience in rescinding Rules and Regulations has been very satisfactory. Rules and Regulations are of no purpose whatsoever, unless they are lawfully made and as our Small Loan Act is complete within itself, we could see no real reason for trying to elaborate on the law.

The success since rescinding the regulations is due largely to a well organized Small Loan State Association, who work very closely with us in trying to follow the intent and purpose of our law. We would not hesitate recommending the rescinding of Rules and Regulations to any State Supervisory agent who has a well organized association, to more or less police themselves. In other words we still have the law in case of a violation, permitting us to rescind the license in case violations are made.

\section{INVESTIGATIONS}

In addition to the annual report that licensees are required to submit to the Banking Department, the Nebraska law provides that the Diréctor of Banking, through his duly appointed Examiners, will conduct a semi-annual investigation of the loans and business of each licensee, together with an examination of its books and records. This is perhaps an over-emphasis and an unnecessary burden on the lenders. In most states, only one such examination is made each year and experience elsewhere had demonstrated that this is of sufficient frequency. (This is not intended to embrace special examinations which the Director may cause to be made at any time when circumstances seem to warrant.) The licensees pay the costs and expenses of these semi-annual examinations so the state has no financial burden in this respect, but each time the state adds to the overhead expense of the lender, there is just that much less chance of a voluntary rate reduction. It seems obvious that needless expense and burden should be avoided, particularly when the lenders' earnings are now no more than fair and are subject to a continuing squeeze because of mounting overhead expense.

\section{Dual Business}

The I94I Nebraska act contained a provision regarding dual business. Under Section $45-123$, it was provided that no licensee shall conduct the business of making loans under the Act within any office, room or place of business where any other business is solicited or engaged in, or in association or conjunction therewith, except as may be authorized in writing by the Director of Banking upon his finding that the character of such other business is such that the granting of such authority would not facilitate evasions of the Act or the rules or regulations lawfully made thereunder. At least in Nebraska that provision was not entirely appropriate. Offices conducting a small loan business would have difficulty surviving in the smaller cities in $\mathrm{Ne}$ braska if they were not permitted to conduct some other type of business, such as real estate, insurance, etc., because the volume of the small loan business would not be sufficient to support the operation on the basis of the rate as limited by the statute. Accordingly, the legislature in 1953 , when examining the law for other minor possible amendments, to be noted later, concluded that the dual business clause should be amended. As changed, the advance written approval of the Director is not required, although the Director may, at any time, order the licensee to dis- 
continue any business conducted in the same office, if such other business would facilitate evasions of the small loan law. ${ }^{12}$

\section{Credit Insurance}

By express language in the I94I act, a licensee was permitted to require a borrower to insure tangible personal property "of a kind usually requiring insurance protection when offered as security for a loan" against any substantial risk or loss, damage or destruction, for an amount and term and upon conditions which are reasonable and appropriate considering the nature of the property and the amount, maturity, and other circumstances of the loan. ${ }^{13}$ The provision that "No other insurance shall be required as a condition precedent to the making of a loan" was construed to mean that a borrower could not be forced to buy other insurance but that small loan companies were authorized to sell credit life, health and accident insurance in connection with the making of loans, where it was purchased on a voluntary basis.

The act was somewhat ambiguous and this construction had to be made by interpretation of the Attorney General and the Department of Banking. This interpretation followed what appeared to be the legislative intent.

With the amendment of the small loan law in $x 953$ (L.B. No. 280), all doubts regarding the sale of credit life and disability insurance have been removed. The legislature has spoken squarely on this subject and the act now specifically provides that such insurance may be written upon any loan in an amount not exceeding the total amount to be repaid under the loan contract and for a term not extending beyond the finakmaturity date of the loan contract. ${ }^{14}$ The law specifically permits the licensee not only to write the insurance, but also to receive commissions from the

12 This change was encouraged by the lenders because the Nebraska Supreme Court in the case of Grand Island Finance Co. v. Eacker, ,I55 Neb. 546, 52 N. W. 2d 805 (I952), invalidated a small loan contract for a technical violation of the dual business provision of the act. The written approval for dual business in that case did not cover one or two minor items of business carried on by the licensec.

${ }^{13}$ A charge for an insurance premium was held to be a proper item to include in a loan. Underwriters Acceptance Corp. v. Dunkin, I52 Neb. 550, 4 I N. W. 2 d 855 (1950).

${ }^{14}$ The insurance provision in the Nebraska Small Loan Law was changed by an amendment (L.B. No. 280) approved by the Governor on April II, I953, so as to read as follows:

"The following types of insurance may be written in connection with loans made by licensces under $\$ \$ 45-I_{4}$ and 45-155: ( $\mathrm{x}$ ) Fire, theft, windstorm; or comprehensive, including fire, theft, and windstorm; fifty dollars or more deductible collision; bodily injury liability and property damage liability upon motor vehicles; (2) fire and extended coverage insurance upon real and tangible personal property; (3) life, health, and accident insurance, or any of them may also be written upon any loan in an amount not exceeding the total amount to be repaid under the loan contract, and for a term not extending beyond the final maturity date of the loan contract; Provided, that in the event of a renewal of a contract of loan, this type of insurance shall be cancelled and a refund of the uncarned premium creditcd or made before new insurance of this type may be written in connection with such loan.

"Notwithstanding the provisions of $\$ \$ 45-137$ and $45-138$, any gain or advantage, in the form of commission or otherwise, to the licensee or to any employee, affiliate or associate of the licensce from such insurance or its sale shall not be deemed to be an additional or further charge in connection with the contract of loan. The insurance premium for such insurance may be collected from the borrower or included in the contract of loan at the time the loan is made. Insurance permitted as aforesaid shall be obtained through a duly licensed insurance agent, agency, or broker. Premiums shall not exced those fixed by law or current applicable manual rates. Insurance written as above authorized may contain a mortgagee clause or other appropriate provision to protect the insurable interest of the licensec." 
premiums in connection therewith. The act continues to provide that insurance cannot be required as a condition precedent to the making of the loan. In addition, there is to be only one policy in force and, upon a renewal or a new loan to a present customer, the previous policy must be canceled.

As amended, the law is clear and there is no need for departmental rules or regulations. The official view in Nebraska was in accord with the recommendation set out in the Report of the Insurance Committee of the National Association of Small Loan Supervisors in its session of September 17-20, 1950. At that time, the Committee concluded as follows:

It appears as though the legislature should definitely determine, in each instance, whether or not insurance is to be sold by small loan companies, setting out fully the rights, limitations and restrictions.

\section{SECURITY}

The Nebraska act departs from the standard pattern of small loan laws in that it does not prohibit a licensee from taking a lien upon real estate as security for a loan made under the small loan law. In practice, however, real estate mortgages are seldom taken in connection with small loans. The 1952 Consolidated Report issued by the Banking Department and covering the I40 licensed small loan companies shows that only 569 loans were made during the year of 1952 secured by real estate. This was out of a total of $x_{04,856}$ loans. During that period, a total of 36,478 loans were secured by household goods and 26,500 loans were secured by automobiles. The $195^{2}$ Consolidated Report contains the following over-all showing regarding types of security:

Classification of Loans by Type of Security

Small loans made during the year secured by:

\begin{tabular}{cr}
$\begin{array}{c}\text { Number of } \\
\text { Accounts }\end{array}$ & \multicolumn{1}{c}{ Amount } \\
36,478 & $\$ 13,463,058$ \\
26,500 & $11,532,501$ \\
10,236 & $4,520,396$ \\
26,371 & $5,805,129$ \\
2,072 & 432,446 \\
1,793 & 341,235 \\
569 & 358,866 \\
837 & 484,567 \\
\hline 104,856 & $\$ 36,938,198$
\end{tabular}
(a) Household goods
(b) Automobiles
(c) Other chattels
(d) Unsecured
(e) Comaker, endorsed or guaranteed
(f) Wage assignment
(g) Real estate
(h) Other consideration
(i) Total

As will be noted in the following section, it is seldom the practice of lenders actually to seize possession of and sell the security as a means of collecting an account in full or in part.

\section{Collection Practices}

It has been publicly charged from time to time that small loan companies use harsh and abusive tactics in collecting from delinquent borrowers. In some cases 
these allegations have been, made on a national bașis. As the Nebraska Supervisor of Small Loans, I will endeavor to point out only the practices in Nebraska.

At various times representatives of the Banking Department made personal investigations and inquiries of borrowers (classified as to those with delinquent and those with prompt accounts) as to the treatment received from the Nebraska licensees. The Department has considered that it is its public duty to determine just what practices are being used by the small loan companies in this state.

As a background to this investigation, it was found that nearly 83 per cent of the loans made are for the purpose of consolidating debts already contracted and owing to doctors, dentists, hospitals, department stores, furniture and appliance stores, and many other sources. This means that most of the loans made by the Nebraska licensees are for the purpose of helping the debt-laden person through the payment of his numerous bills by consolidating his obligations into one contract to be repaid upon a budget plan. The investigation disclosed that the tactics used in collecting from borrowers of this type compared favorably with the collection tactics used by credit departments of some stores, professional bill collectors, and attorneys.

In practically all cases of inquiry we have found that the treatment received from small loan companies was far superior to that received from other sources where the overdue accounts originated. Many of the people offered high praise for the service rendered to them by the small loan companies in helping them to budget their indebtedness and pay for it on an orderly payment plan. Previously they were bothered by collectors from various stores at all times of day and night which disrupted them in many ways. They said that some collectors had been very abusive and had approached them in such ways and times as to make it very embarrassing.

A very interesting observation was made when it was discovered that in some instances where a customer had paid off his open accounts by the consolidation of his debts through the assistance of a small loan company, the salesmen for some of the same merchants then solicited the borrower again to get in debt with new purchases. It appears to be a continuous cycle.

As the experience in 1952 demonstrates, legal action against borrowers is comparatively infrequent. Out of a total of 104,856 accounts, suits were instituted in only 321 cases. Actual seizure of security as a collection means was also uncommon as a glance at the following chart will show:

\section{Possession of Chattels}

\begin{tabular}{lccccc} 
& \multicolumn{2}{c}{ WHEN IN USE } & \multicolumn{2}{c}{ WHEN Nor IN UsE } \\
& $\begin{array}{c}\text { Number of } \\
\text { Accounts }\end{array}$ & $\begin{array}{c}\text { Loan } \\
\text { Balance Due }\end{array}$ & $\begin{array}{c}\text { Number of } \\
\text { Accounts }\end{array}$ & $\begin{array}{c}\text { Loan } \\
\text { Balance Due }\end{array}$ \\
Household goods & I9 & $\$ 5,646$ & 15 & $\$ 6,745$ \\
Automobiles & 67 & 26,619 & 50 & 18,555 \\
Other Chattels & II & 2,720 & 6 & 2,826
\end{tabular}

The periodic investigations reveal that the Nebraska small loan companies have been and are now using reasonable collection practices. The Department plans to 
continue periodic surveys because it is believed to be important to the licensees and the industry in general.

\section{Conceusion}

Looking over the small loan situation in Nebraska with a rather critical eye, it appears that from the borrower's standpoint, the atmosphere is conducive to fair treatment and good loan service-all at a reasonable rate of charge. From the lender's outlook, there is a good prospect of a fair and reasonable return based on money loaned, services rendered, and expenses incurred. (For instance, in Nebraska in 1952 the per cent of net earnings calculated upon average assets employed (I) before interest paid on borrowed money was 7.28 per cent, and (2), after interest paid on borrowed money was 3.86 per cent.) By virtue of the small loan law and the careful supervision thereunder, there is no great disparity in the bargaining power between the borrower and lender. The Banking Department of Nebraska intends to do all in its power to keep it that way.

The disturbing activity and influence of the loan shark is today at more than a low ebb in Nebraska. It is virtually non-existent. (It would be Utopia to expect that an occasional shark would not try to stick his head under the tent.) This almost complete absence of loan sharks is the most important reason why the borrowers of Nebraska are receiving the good small loan service they deserve. It is the job of the Banking Department to make sure that this attractive picture is not marred.

The loan shark has been described as a lender of small sums at high rates on the sleazy chattels of the unfortunate or improvident. This unattractive character is a pest that can grow up in our midst or blow in from afar. Progressively, we have been more successful in the extermination of that operator. The loopholes in our earliest law have been plugged up in successive steps. At the present time, the state of Nebraska enjoys almost complete freedom from this evil force. That does not mean we can relax, for Nebraska is vulnerable to the possible return of loan sharks because they are still alive in nearby states. South Dakota passed its first effective small loan law in 1953. If it is well administered, as we think it will be, the loan sharks that did business there will be looking for a new camping ground. Kansas is still infested with the high-raters, and these operators are looking for a bigger territory. North Dakota and Montana are unregulated states from the standpoint of small loans. Consequently, we in Nebraska must continue to be alert. Freedom from loan sharks is based upon eternal vigilance. 